\title{
Research on Music Teaching Reform in Colleges and Universities from the Perspective of MOOC
}

\author{
Ying Wang ${ }^{1}$, Wei Zhou ${ }^{2}$ \\ ${ }^{1}$ Jiangxi Science \& Technology Normal University, Jiangxi Province, Nanchang, 330013 \\ ${ }^{2}$ Nanchang Normal University, Jiangxi Province, Nanchang, 330032
}

Keywords: MOOC, College Music; Teaching Reform

\begin{abstract}
The development of the Internet and the popularity of electronic devices speeds up the network and the arrival of the era of data. MOOC as a new large-scale open online course meets people's teaching resources and teaching information needs. MOOC gradually applied to the major colleges and universities' teaching class, the emergence of MOOC changed the traditional teaching methods, greatly improving the quality of teaching and students' learning efficiency. In the future, MOOC will become the main teaching methods of colleges and universities, and promote the development of teaching reform in colleges and universities. College music teaching is a more practical subject and music teaching in the use of MOOC teaching can achieve higher teaching efficiency? This paper mainly aims at the basic characteristics of music teaching reform in colleges and universities based on the view of MOOC and explore the role of MOOC in teaching music in colleges and universities.
\end{abstract}

\section{Introduction}

MOOC as a new network platform teaching courses, students can access anytime, anywhere teaching resources to learn. MOOC is the most high-end online curriculum development model, which involves a wide range of professional knowledge and the general university disciplines in the course can be searched. Among them, the teaching of music in colleges and universities is a relatively strong subject, the invention and promotion of MOOC to promote the transformation of traditional teaching methods, breaking the traditional college music teaching model. How to use the MOOC in colleges and universities to improve the quality of teaching and learning efficiency is a questionable issue in our university. In recent years, colleges and universities for the use of music in the teaching of music is more common, this new teaching methods not only stimulate the students' interest in learning, but also greatly improve the quality of college music teaching.

\section{The Role of MOOC for College Music Teaching Reform}

MOOC Achieves the Teacher-Student Relationship Flip. The emergence of "MOOC" has promoted the reform of music teaching in colleges and universities, it is the need of the development of higher education and MOOC in the use of music classroom has a more positive role. First of all, MOOC changes college music teaching time and space constraints, allowing students to study anytime, anywhere, greatly improving the enthusiasm and initiative of students. The traditional music teaching in colleges and universities has always emphasized the teacher as the dominant position, MOOC appeared to achieve the conversion of college teachers and students identity, improve the autonomy of student teaching. Teachers to help students solve the problem through learning not only enhance the activity of college music classroom, but also greatly improve the quality of music teachers teaching [1].

MOOC Promotes the Music Teaching Reform in Colleges and Universities. MOOC can be taught through the Internet in a timely manner, the course of the course open to expand the number of Internet audiences, so that everyone can learn through MOOC. The emergence of MOOC 
changed the limitations of traditional Chinese education, expanding the scope and depth of learning. MOOC to data and network as a support to change the traditional music teaching methods and learning methods, so that college music teaching more diversity and openness. The emergence of MOOC has added the interest of college music classroom, greatly enhanced the motivation and autonomy of students' music learning. MOOC and even promote the reform of more teaching models, such as video live teaching.

\section{An Analysis of the Reform of Music Teaching in Colleges and Universities}

Analysis on the Advantages of MOOC in Music Teaching Reform in Colleges and Universities. MOOC is in the use of music teaching in colleges and universities, the general use of network music teaching information resources, to achieve $\mathrm{Mu}$ teaching and traditional teaching combination. In the course of college music teaching, colleges and universities in addition to the application of language teaching, but also should be combined with multimedia teaching. Music teachers in colleges and universities should strengthen the innovation of music theory teaching and realize the sharing function of teaching resources in class. MOOC is in the use of music teaching in colleges and universities, for students to provide information network of resources to learn ways. It can enable students to enjoy the music through the MOOC online music, so as to improve their own music appreciation ability [2]. It is difficult to improve the students' ability of music appreciation by teaching the textbooks in colleges and universities. MOOC online music appreciation courses generally use music and explain the combination of the form, which undoubtedly greatly improve the student's music content and music accomplishment. Network courses for students to provide a large number of music learning materials, music lectures, music expert courses, you can listen to many of Chinese outstanding musicians and professors to explain, can make students subtle improvement of their own music accomplishment.

Analysis on the Disadvantages of MOOC in Music Teaching Reform in Colleges and Universities. MOOC plays an important role in the teaching of music in colleges and universities, but there are many problems in the reform of music teaching in colleges and universities. First of all, MOOC music teaching course, while improving the autonomy of students learning, but to reduce the leading music teachers, so that students cannot adapt from the traditional teaching methods. In addition, the teaching of the course requires students to have higher learning initiative and consciousness. If the students' ability of control is poor, the teaching quality of the course is greatly reduced. Finally, the teaching of MOOC needs network technology as a support, but our country's teaching infrastructure is not perfect, college music teachers lack the appropriate operational skills and so on [3]. All in all, MOOC in the use of music teaching and practice has yet to be strengthened.

\section{The Reform Strategy of Music Teaching in Colleges and Universities from the Perspective of MOOC}

Strengthen the Attention of Music Teachers in Colleges and Universities on the "MOOC". MOOC is an emerging network of curriculum design and MOOC in the application of teaching in colleges and universities is still in the early stages of the experiment. Colleges and universities should strengthen the understanding of the openness and flexibility of the curriculum resources of the catches, so that the catches play a real role in the college music classroom. MOOC teacher will be music teachers and students and MOOC curriculum integration, music teachers should change the traditional teaching thinking, understanding of the lessons of traditional music teaching for the great changes brought about. Music teachers in colleges and universities need to accept new things, improve MOOC for music teaching in the position. Music teachers in the music curriculum design can use MOOC teaching, music classroom teaching links in the insert MOOC course, music student achievement evaluation is also able to complete through the MOOC online. In addition, $\mathrm{Mu}$ students need students with a high degree of autonomy, music teachers should strengthen the guidance of students, through post-class assignments, etc., the students and MOOC together. 
Colleges and Universities Should Strengthen the Construction of Information Technology Infrastructure. MOOC music teaching to achieve higher technical support, students can through the Internet information technology and music teachers online communication. MOOC achieve the college music teaching network teaching mode, music teachers can keep abreast of the network platform through the confusion and problems and guidance. MOOC is mainly to the Internet as a core platform to promote the use of teaching resources for a large number of storage, and to achieve a network of sharing. MOOC in the use of music classroom in colleges and universities not only need the attention of educators, but also the need for technical personnel for the management of MOOC management, but music teachers do not have the ability to promote. Colleges and universities should strengthen the capital development of mu - class course and train high - quality technical network talents. Colleges and universities should regularly set up professional training courses, the network of teachers to train the knowledge, improve the teachers' understanding of the teachers and the use of management capacity.

Strengthen the Combination of Micro-Public Platform and Music Teaching Reform. MOOC music under the perspective of promoting the reform of music teaching in colleges and universities, music teaching can use the micro-public platform, music online video teaching, students can choose their own interest in selective learning. We-Chat public number teaching, including music course video teaching, as well as excellent classical music material, teachers can consciously guide the students concerned about the micro-public platform, and I do not know the corresponding class tasks, encourage students to watch We-Chat video to complete, in order to achieve teaching the goal of. In addition, the We-Chat public platform also narrowed the distance between the educators and students, students can feedback through the micro-platform in time to learn the problem, college music teachers by answering questions, is conducive to improving the enthusiasm and initiative of student music learning [4].

\section{Conclusion}

Information and data age background, Chinese traditional music education methods are no longer suitable for social development needs. Music teachers should understand the use of MOOC network resources and network technology. MOOC the emergence of MOOC to achieve the teacher-student relationship between the flip, the teaching of music in our country is also a major change. MOOC can realize the resource sharing of music theory teaching in colleges and universities and greatly improve the music appreciation ability and music accomplishment of music students. However, there are still some drawbacks in the reform of music teaching in colleges and universities. Therefore, colleges and universities must study the reform of music teaching from the perspective of MOOC. First of all, college music teachers should strengthen the importance of MOOC awareness, colleges and universities should strengthen the information technology infrastructure construction. The further development of music teaching reform in colleges and universities has been promoted.

\section{Acknowledgements}

Fund Project: "Research on the application of MOOC in the teachers in the teachers' music teaching" Jiangxi Provincial Department of Education Humanities Youth Project JY162058

\section{References}

[1] Pan Yanna. "Folk knowledge" in college classroom "discourse" conversion - to Guangzhou University Music and Dance Academy "Chaozhou big gongs and drums" course as an example [J]. Music, 2015, (12): 190- 192.

[2] Feng Zhiming. The reform practice of Chinese teaching method of art major - Based on the perspective of "research teaching" and anthropology curriculum view[J]. University Education, 2014, (03): 107-108. 
[3] Zhang Qiang. Music teaching in the "music study and folk songs" teaching work - to Shihezi University Music (Normal) professional as an example [J]. Big stage, 2011, (01): 234-235.

[4] Zhou Shibin. Dialysis phenomenon is intended to see the full bustling worries (on) - by the status quo of Chinese higher professional music education thinking [J]. Musical Instruments, 2007, (03): 24-25. 